University of California, Hastings College of the Law UC Hastings Scholarship Repository

Faculty Scholarship

1988

\title{
A Cause of Action for Option Traders Against Insider Option Traders
}

William K.S. Wang

UC Hastings College of the Law, wangw@uchastings.edu

Follow this and additional works at: http://repository.uchastings.edu/faculty_scholarship

Part of the Securities Law Commons

\section{Recommended Citation}

William K.S. Wang, A Cause of Action for Option Traders Against Insider Option Traders, 101 Harv. L. Rev. 1056 (1988).

Available at: http://repository.uchastings.edu/faculty_scholarship/757

This Article is brought to you for free and open access by UC Hastings Scholarship Repository. It has been accepted for inclusion in Faculty Scholarship

by an authorized administrator of UC Hastings Scholarship Repository. For more information, please contact marcusc@uchastings.edu. 


\title{
Faculty Publications \\ UC Hastings College of the Law Library
}

\author{
Author: William K.S. Wang \\ Source: Harvard Law Review \\ Citation: 101 Harv. L. Rev. 1056 (1988). \\ Title: $\quad$ A Cause of Action for Option Traders Against Insider Option Traders
}

Originally published in HARVARD LAW REVIEW. This article is reprinted with permission from HARVARD LAW REVIEW and Harvard Law School . 


\title{
A CAUSE OF ACTION FOR OPTION TRADERS AGAINST INSIDER OPTION TRADERS
}

\author{
William K.S. Wang*
}

A recent Note in this Review argued that a cause of action should be available under rule $10 \mathrm{~b}-5^{1}$ for traders of options on corporate stock against insider traders of options on the same stock. ${ }^{2}$ Surprisingly, the Note ignored the fact that Congress has already approved such an action in section 2o(d) of the Insider Trading Sanctions Act of $1984 .{ }^{3}$ The Note acknowledged that "section 20 (d) ... ma[de] insider trading or tipping in stock options unlawful to the same extent as trading or tipping in the underlying security," but the author erroneously concluded that "[ $t]$ his provision applies only to SEC enforcement suits." 4

The Note's restrictive interpretation is plainly wrong. Section $20(d)$ provides:

Wherever communicating, or purchasing or selling a security while in possession of, material nonpublic information would violate, or result in liability to any purchaser or seller of the security under any provision of this chapter, or any rule or regulation thereunder, such conduct in connection with a purchase or sale of a put, call, straddle, option, or privilege with respect to such security or with respect to a group or index of securities including such security, shall also violate and result in comparable liability to any purchaser or seller of that security under such provision, rule, or regulation. ${ }^{5}$

* Professor of Law, University of California, Hastings College of Law.

1 I7 C.F.R. \& 240 . Iob-5 ( 1987 ). Rule Iob-5 was adopted pursuant to $\$$ ro(b) of the Securities Exchange Act of 1934. 15 U.S.C. § $78 \mathrm{j}(\mathrm{b})$ (1982).

${ }^{2}$ See Note, Private Causes of Action for Option Investors Under SEC Rule rob-5: A Policy, Doctrinal, and Economic Analysis, Ioo HaRv. L. Rev. 1959 (1987). In addition, the Note argued that options traders should be allowed to sue insider traders of stock and to sue corporations whose misstatements affect stock and option prices. See id. at 1964, 1967, 1973, I976-78.

The issue whether an options trader can sue an insider options trader is distinct from the issue whether an options trader can sue an insider stock trader. Courts are divided on the latter question. Compare Laventhall v. General Dynamics Corp., 704 F.2d 407 (8th Cir.), cert. denied, 464 U.S. 846 ( 1983 ) (not allowing suit) and Starkman v. Warner Communications, Inc., 671 F. Supp. 297, 301-07 (S.D.N.Y. 1987) (same) with Backman v. Polaroid Corp., 540 F. Supp. 667, 67I (D. Mass. I982) (allowing standing to sue an insider stock trader but not deciding whether the plaintiff could establish damage).

3 Pub. L. No. $98-376,98$ Stat. 1265 (1984) (codified as amended at 15 U.S.C. $\$ 78 t$ (d) (Supp. III rg85)).

4 Note, supra note 2 , at 1962 (footnote omitted).

5 I5 U.S.C. \& $78 \mathrm{t}$ (d) (Supp. III I985) (emphasis added). Section $20(d)$ closed a possible loophole in rule rob-5 insider trading liability created by Chiarella v. United States, 445 U.S. 222 (1980). Chiarella emphasized as a basis for insider trading liability a relationship of "trust 
Although the reference to "comparable liability" leaves open important questions concerning the extent of the plaintiff class $^{6}$ and the nature of the remedy, the last clause of this provision unambiguously refers to private causes of action.

The clause is ambiguous, however, in its reference to "that security." The phrase could mean either the underlying security (for example, the common stock) or the derivative security (for example, the option). ${ }^{7}$ Under the first interpretation, Congress authorized a private cause of action against insider option traders only for plaintiffs who had traded the underlying stock. Under the second interpretation, Congress authorized a private cause of action against insider option traders only for plaintiffs who had traded the equivalent option. ${ }^{8}$

Only the second interpretation makes sense. Congress could not have intended to exclude the person on the other side of the trade from the class of "purchaser[s] or seller[s] of that security" authorized to act as plaintiffs. The legislative history of the Insider Trading Sanctions Act makes clear that the troublesome phrase "that security" refers to the derivative security. In I984, Senator Alfonse D'Amato was chair of the Subcommittee on Securities of the Senate Committee on Banking, Housing, and Urban Affairs. When the Insider Trading Sanctions Act was introduced on the Senate floor, Senator D'Amato's remarks in support of the bill included the following illustration of the effect of section $20(d)$ :

and confidence" between the parties to the insider trade. Id. at 230-33. For a discussion of Chiarella's "special relationship" theory, see Wang, Trading on Material Nonpublic Information on Impersonal Stock Markets: Who is Harmed, and Who Can Sue Whom Under SEC Rule Iob-5?, 54 S. CAL. L. REV. 12 7 7, 1269-71, 1285-94 (198I). An insider trader of options may not have such a relationship of "trust and confidence" to the party on the other side of the transaction. See id. at I286-87; cf. Laventhall, 704 F.2d at 4II-12 (finding no relationship of trust and confidence between a plaintiff options trader and a defendant insider trader of the underlying stock).

In its Supreme Court brief, the United States advanced an alternative theory to justify Chiarella's conviction. The brief argued that, by trading, Chiarella, whose direct employer was a financial printer preparing takeover announcements, breached his duty to his indirect employers, the acquiring corporations. See Chiarella, 445 U.S. at 235. The Court did not rule on the validity of this "misappropriation theory" because it had not been submitted to the jury. See id. at 235-36. See generally Wang, supra, at 1271-74, 1294-97 (discussing the 10b-5 "misappropriation theory"); infra note $\mathrm{r}_{3}$ (discussing the theory's use by private plaintiffs). In Carpenter v. United States, I08 S. Ct. 316 (I987), an evenly divided Supreme Court upheld criminal convictions under $\S$ Io(b) and rule Iob-5 based on the "misappropriation theory," but the opinion dealt only with the defendants' concurrent mail and wire fraud convictions (which the Court upheld unanimously). The four Justices who voted to reverse the convictions under $\S \mathrm{Io}(\mathrm{b})$ and rule Iob-5 gave neither their reasons nor their names. See id. at 320.

${ }^{6}$ See infra notes $12-13$.

${ }^{7}$ For a more detailed analysis of this ambiguity in section $20(\mathrm{~d})$, see Wang, The "Contemporaneous" Traders Who Can Sue an Inside Trader, 38 Hastings L.J. II75, II88-9x (1987).

8 Apparently, no reported case has interpreted $\$ 20(d)$ since the Insider Trading Sanctions Act's enactment in August I984. 
For example, if, in a given set of circumstances, a corporate officer would violate the antifraud provisions by purchasing any securities issued by his employer, subjecting himself to liability to selling shareholders, then he would violate the antifraud provisions to the same extent by purchasing options with respect to these securities, and subject himself to comparable liability to selling option holders and other similarly situated persons in the derivative market. ${ }^{9}$

The Senate added section $20(d)$ to a bill passed by the House. ${ }^{10}$ In I984, Congressman John Dingell was chair of the House Committee on Energy and Commerce. When Congressman Dingell introduced the final version of the Insider Trading Sanctions Act on the floor of the House, he inserted in the Congressional Record an explanation of various Senate amendments and included (verbatim) the same example quoted above. ${ }^{11}$

Both the language of section $20(d)$ and its legislative history indicate that Congress presumed that at least some private stock-trading plaintiffs had an implied cause of action against certain insider traders of publicly traded stock. Although the Supreme Court has never directly addressed this issue, ${ }^{12}$ judicial precedent in the Second Cir-

${ }^{9}$ I30 Cong. REC. S8gr3 (daily ed. June 29, 1984) (statement of Sen. D'Amato) (emphasis added).

${ }^{10}$ See I30 Cong. REc. $\mathrm{H}_{7757}$ (daily ed. July 25, 1984) (statements of Reps. Broyhill and Dingell).

${ }^{11}$ See id. at $\mathrm{H}_{7758}$ (statement of Rep. Dingell); Wang, supra note 7 , at $1189-90$ (discussing the legislative history of $\S 20(d))$. There was neither a Senate Banking Committee report nor a House-Senate conference report on any of the Senate amendments to the Insider Trading Sanctions Act, including $\S 20$ (d). See I30 CoNG. REc. H7758 (statement of Rep. Dingell).

12 The leading Supreme Court insider trading cases involving rule 10b-5 are Chiarella v. United States, 445 U.S. 222 (1980), and Dirks v. SEC, 463 U.S. 646 (1983); neither was a private civil action for damages. As I read Chiarella, the Court is suggesting that an implied rule rob-5 cause of action under the "special relationship" theory exists but that the only private party who can sue an insider trader on this ground is the party on the other side of the trade. See Wang, supra note 5, at $1270-7 \mathrm{I}$. Identifying the party in privity with a stock market insider trader is not as difficult as many commentators believe. See Wang, supra note 7 , at II 79 n.20.

Harvey Pitt's analysis of Chiarella is similar. See Pitt, After the Fall: The Ins and Outs of Rule $10 b-5$, in Twelfth ANnUal Institute on Securities Regulation 643, 662-63 (A. Fleischer, M. Lipton \& R. Mundheim eds. 1980). Although Chiarella was a criminal case, the Second Circuit has relied on it to deny standing to a class of private civil plaintiffs. See Moss v. Morgan Stanley, Inc., 7 19 F.2d 5 (2d Cir. 1983), cert. denied sub nom. Moss v. Newman, 465 U.S. I025 (1984); see also infra note I3 (discussing Moss).

Nevertheless, many commentators disagree with my conclusion that only the party in contractual privity can bring a private rob-5 action against the stock market insider trader under the "special relationship" theory. Professor Langevoort, for example, states:

It is possible to read Chiarella as saying that only the party in privity has standing to sue. ... But this is little more than inference drawn from dicta, probably not enough to overcome the legitimate concern expressed in Shapiro that a privity requirement in the context of open market insider trading would be foolishly formalistic .... .

D. LANGevoORT, INSIDER Trading HANDBOoK 285-86 (I987); accord Note, Laventhall v. General Dynamics Corporation: No Recovery for the Plaintiff-Option Holder in a Case of Insider 
cuit, the most important circuit in securities litigation, supported Congress' assumption that some stock traders could sue certain stock market insider traders. ${ }^{13}$ The intent of section $20(d)$ was to allow

Trading Under Rule rob-5, 79 Nw. U.L. REv. 780,792 n.72 (1984) ("The Court sought to limit only the defendant class ... and did not consider, even in passing, what group of investors might comprise the plaintiff class ...."). Several courts and commentators have concluded that, despite Chiarella and Dirks, "contemporaneous" traders have a rule rob-5 cause of action against a stock market insider trader liable under the "special relationship" theory. See, e.g., In re McDonnell Douglas Corp. Sec. Litig., 587 F. Supp. 625, 630 (E.D. Mo. 1983) (stating that although Dirks reaffirmed the special relationship requirement, "[t]he Supreme Court did not discuss or limit the application of the 'contemporaneous trading' rule"); 5 A A. JACOBS, Litigation AND PRACTICE UNDER RULE IOB-5 $\$ 66.02$ [a][iii][D] (2d rev. ed. I987). Ironically, the Second Circuit has applied Chiarella to limit the class of plaintiffs who can sue "misappropriators," but not the class of plaintiffs who can sue an insider trader liable under the "special relationship" theory endorsed in Chiarella. See infra note $\mathrm{r} 3$.

I may be wrong in concluding that under Chiarelle only the party in contractual privity can sue a stock market insider trader who breaches a rule Iob-5 "special relationship." Even so, the class of plaintiffs allowed to sue such a defendant should include at least the party on the other side of the transaction. Such a plaintiff should have the right to rescind under section 29(b) of the Securities Exchange Act of 1934, I5 U.S.C. \& 78cc (1982), which renders voidable any contract made in violation of the Act or of any rule promulgated thereunder. See generally Gruenbaum \& Steinberg, Section 29(b) of the Securities Exchange Act of 1934: A Viable Remedy Awakened, 48 GEO. WASH. L. REV. I (1979).

${ }^{13}$ In that Circuit, a stock market insider trader who violates rule rob-5 under the "special relationship" theory becomes liable to "contemporaneous" traders. See Wilson v. Comtech Telecommunications Corp., 648 F.2d 88, 94-95 (2d Cir. 198I); see also Wang, supra note 5, at 1279-82 (discussing the Wilson case); Wang, supra note 7 (discussing the meaning of "contemporaneous"). Although decided after Chiarella, Wilson does not cite the Supreme Court's opinion. District courts in the First and Eighth Circuits have endorsed Wilson's "contemporaneous" plaintiff class. See, e.g., Abelson v. Strong, 644 F. Supp. 524 (D. Mass. 1986); In re McDonnell Douglas Corp. Sec. Litig., 587 F. Supp. 625, 630 (E.D. Mo. 1983) (citing dictum from Laventhall v. General Dynamics Corp., 704 F.2d 407, 412 (8th Cir.), cert. denied, 464 U.S. 846 (I983)). But cf. Fridrich v. Bradford, 542 F.2d 307 (6th Cir. 1976), cert. denied, 429 U.S. 1053 (1977) (attempting to outline what a private plaintiff suing a stock market insider trader under rule rob-5 must demonstrate, but failing to explain clearly whether the essential element is privity of contract, causation of harm by the insider's act of trading, either of the above, or both). See generally Wang, supra note 5 , at 1262-67, 1284, 1316 (analyzing Fridrich).

The Second Circuit has since held that trading stock on material nonpublic information does not make the defendant trader liable to "marketplace," or even "contemporaneous," traders, if liability under rule Iob-5 is based on the "misappropriation" theory. See Moss, 719 F.2d at 1013, 15-16. See generally supra note 5. Moss at least limits the scope of Wilson's "contemporaneous trader" holding. One might argue that Moss raises doubts as to Wilson's continued vitality. Moss does not refer to Wilson, however. Therefore, the appropriate interpretation of Moss is that it implicitly limits the Wilson holding to defendants who breach a "special relationship."

The above discussion deals with rule Iob-5. Under certain circumstances, rule I4e-3, I7 C.F.R. \$ 240.14e-3 ( 1987 ), prohibits individuals from tipping or trading on the basis of material information about an impending tender offer. One lower court, for example, has allowed a private cause of action for "relief" (presumably damages) under rule 14e-3. See O'Connor \& Assoc. v. Dean Witter Reynolds, Inc., 529 F. Supp. II79 (S.D.N.Y. 198I) (allowing plaintiff options sellers to sue defendant options buyers); $c f$. Burlington Indus., Inc. v. Edelman, Fed. Sec. L. Rep. (CCH) I 93,339 (4th Cir. 1987), aff'g on the opinion below 666 F. Supp. 799 (M.D.N.C. 1987) (holding that a target company has standing to obtain a preliminary injunction against possible rule 14 e-3 violations). See generally D. LANGEVooRT, supra note $12, \S 9.04$. 
analogously situated option-trading plaintiffs an equivalent private cause of action against insider traders of options. In short, the legislative history of section 20 (d) clearly demonstrates that Congress enacted the provision to remedy one of the problems discussed in the Note. A private cause of action against insider traders of options is now available to option-trading plaintiffs. 